\title{
The Impact of Ship-Produced Aerosols on the Microstructure and Albedo of Warm Marine Stratocumulus Clouds: A Test of MAST Hypotheses 1i and 1ii
}

\author{
P. A. Durkee, ${ }^{a}$ K. J. Noone, ${ }^{b}$ R. J. Ferek,,${ }^{c} *$ D. W. Johnson, ${ }^{d}$ J. P. Taylor,${ }^{d}$ T. J. Garrett, ${ }^{c}$ \\ P. V. Hobbs, ${ }^{c}$ J. G. Hudson, ${ }^{e}$ C. S. Bretherton, ${ }^{c}$ G. InNIS,,${ }^{f}$ G. M. Frick,,${ }^{g}$ W. A. Hoppel,,${ }^{g}$

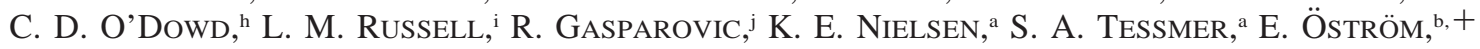 \\ S. R. Osborne, ${ }^{d}$ R. C. Flagan, ${ }^{k}$ J. H. Seinfeld, ${ }^{k}$ And H. Rand ${ }^{c}$ \\ ${ }^{a}$ Department of Meteorology, Naval Postgraduate School, Monterey, California \\ ' Stockholm University, Stockholm, Sweden \\ c University of Washington, Seattle, Washington \\ ${ }^{d}$ The Met. Office, Farnborough, United Kingdom

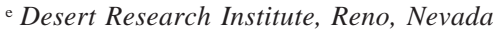 \\ ${ }^{\mathrm{f}}$ SAIC, San Diego, California \\ s Naval Research Laboratory, Washington, D.C. \\ ${ }^{\text {h } U n i v e r s i t y ~ o f ~ S u n d e r l a n d, ~ S u n d e r l a n d, ~ U n i t e d ~ K i n g d o m ~}$ \\ i Princeton University, Princeton, New Jersey \\ ${ }^{\mathrm{j}}$ Applied Physics Laboratory, The Johns Hopkins University, Laurel, Maryland \\ ${ }^{\mathrm{k}}$ California Institute of Technology, Pasadena, California
}

(Manuscript received 22 October 1997, in final form 12 February 1999)

\begin{abstract}
Anomalously high reflectivity tracks in stratus and stratocumulus sheets associated with ships (known as ship tracks) are commonly seen in visible and near-infrared satellite imagery. Until now there have been only a limited number of in situ measurements made in ship tracks. The Monterey Area Ship Track (MAST) experiment, which was conducted off the coast of California in June 1994, provided a substantial dataset on ship emissions and their effects on boundary layer clouds. Several platforms, including the University of Washington C-131A aircraft, the Meteorological Research Flight C-130 aircraft, the National Aeronautics and Space Administration ER-2 aircraft, the Naval Research Laboratory airship, the Research Vessel Glorita, and dedicated U.S. Navy ships, participated in MAST in order to study processes governing the formation and maintenance of ship tracks.

This paper tests the hypotheses that the cloud microphysical changes that produce ship tracks are due to (a) particulate emission from the ship's stack and/or (b) sea-salt particles from the ship's wake. It was found that ships powered by diesel propulsion units that emitted high concentrations of aerosols in the accumulation mode produced ship tracks. Ships that produced few particles (such as nuclear ships), or ships that produced high concentrations of particles but at sizes too small to be activated as cloud drops in typical stratocumulus (such as gas turbine and some steam-powered ships), did not produce ship tracks. Statistics and case studies, combined with model simulations, show that provided a cloud layer is susceptible to an aerosol perturbation, and the atmospheric stability enables aerosol to be mixed throughout the boundary layer, the direct emissions of cloud condensation nuclei from the stack of a diesel-powered ship is the most likely, if not the only, cause of the formation of ship tracks. There was no evidence that salt particles from ship wakes cause ship tracks.
\end{abstract}

\section{Introduction}

One of the largest uncertainties in estimates of radiative forcing of the earth's atmosphere is the indirect

\footnotetext{
*Current affiliation: Office of Naval Research, Washington, D.C. ${ }^{+}$Current affiliation: U.K. Meteorological Office, Farnborough, United Kingdom.

Corresponding author address: Prof. Philip A. Durkee, Department of Meteorology, Naval Postgraduate School, 589 Dyer Road, Monterey, CA 93943-5113.

E-mail: durkee@nps.navy.mil
}

effect of aerosols on cloud albedo (IPCC 1995). Stratus and stratocumulus clouds, which occur in persistent sheets covering large areas of the eastern parts of subtropical ocean basins, have relatively high albedo and therefore reduce the shortwave radiation received at the earth's surface (Albrecht 1989). The reflectivity of these clouds is very sensitive to their liquid water content (LWC) and droplet size distributions (Slingo 1990). Twomey (1974) suggested that their albedo is modified by the concentrations of cloud condensation nuclei $(\mathrm{CCN})$ on which the droplets form. One of the more convincing pieces of evidence of this is the appearance in visible and near-infrared $(3.7 \mu \mathrm{m})$ satellite images of long-lived, bright cloud lines in the marine boundary 
layer (Conover 1966) and long-lived bright tracks in stratus and stratocumulus layers (Coakley et al. 1987) associated with ships, which are called "ship tracks."

Radke et al. (1989) presented results from aircraft and satellite measurements of two ship tracks that showed a good correlation between the presence of high particle concentrations in ship plumes and increased cloud droplet concentrations. They also found that, for this case, the LWC in ship tracks was higher than in the ambient cloud, which they speculated was due to the suppression of drizzle formation. The University of Washington's (UW) Cloud and Aerosol Research Group (Ferek et al. 1998) obtained the most detailed in situ measurements of ship tracks to date. Their measurements provided strong support for the hypothesis that effluents from ship stacks-increasing the concentration and decreasing the size of cloud droplets - produce ship tracks. They also found that drizzle was suppressed in the observed ship tracks.

Porch et al. (1990) and Hindman et al. (1994) suggested that heat perturbations from ships and air-wake vortices behind ships might be involved in the formation and maintenance of ship tracks.

To better understand the formation of ship tracks, and to ascertain the processes involved in their formation, the Monterey Area Ship Track (MAST) experiment was conducted in June 1994. Four aircraft were involved: the UW's C-131A, the U.K. Meteorological Office's Meteorological Research Flight (MRF) C-130, National Aeronautics and Space Administration's ER-2, and the Naval Research Laboratory's (NRL's) airship. Aircraft measurements were supported by the R/V Glorita, which was instrumented by investigators from The Pennsylvania State University, NRL, Los Alamos National Laboratory, Desert Research Institute, and The Johns Hopkins University. An area off the coast of California was chosen for the field study because persistent stratocumulus clouds occur there and several thousand ship tracks are observed in this region each year during the summer months. Several dedicated ships from the U.S. Navy were used in attempts to produce ship tracks at will. Ship tracks produced by passing merchant ships were also studied.

A series of hypotheses were formulated to test during MAST (Durkee et al. 2000b). The main aim of this paper is to detail the measurements and analysis used to test two of these hypotheses, namely,

- MAST hypothesis $1 i$ : submicron aerosol from the ship stack is responsible for cloud droplet and radiative features of ship tracks, and

- MAST hypothesis 1ii: submicron particles from the water wake are responsible for cloud droplet and radiative features of ship tracks.

Section 2 of this paper details the field experimental procedures and the measurements obtained. Section 3 presents an overview of the experimental data. Results and analysis addressing hypothesis $1 \mathrm{i}$ from several ship tracks including numerical model analyses are summarized in section 4. Section 5 discusses the results pertaining to hypothesis $1 \mathrm{ii}$.

\section{Experimental measurements and procedure \\ a. Platforms and instrumentation}

The measurements and observations presented here were obtained primarily from three platforms: the UW's C-131A, the MRF's C-130, and the NRL airship. A summary of the primary instruments that provided the measurements is given here. Further details of the instrumentation are given by Durkee et al. (2000b).

The main tasks for the aircraft were to measure

- standard meteorological parameters (e.g., temperature, dewpoint, wind speed and direction, and humidity) and the turbulence characteristics of the boundary layer,

- cloud physics and aerosol parameters (e.g., droplet and particle concentrations and sizes),

- the physical and chemical nature of the emissions from ships, and

- radiation parameters (e.g., broadband and narrowband radiances, cloud-top and sea surface temperature).

The standard cloud and aerosol microphysical instruments on the aircraft were augmented in several ways to address MAST hypotheses $1 \mathrm{i}$ and 1ii. On the UW C-131A filter samples were collected in ship plumes and ambient air by rapidly filling a large $2.5-\mathrm{m}^{3}$ grab bag and drawing particles from the bag through a pair of Teflon filters (one fitted with a cyclone to remove particles $>3.5-\mu \mathrm{m}$ diameter, one to collect all particles). Subsequently, the filters were extracted and analyzed by ion chromatography. Salt-particle size distributions were measured with a sodium particle-sizing spectrometer, which uses a flame-photometric detector for sodium (Radke and Hobbs 1969), operated either to sample particles continuously from an isokinetic inlet or from the $2.5-\mathrm{m}^{3}$ grab bag.

The UW C-131A also carried three instruments from other institutions. The Desert Research Institute CCN counter is described by Hudson (1991). The Counterflow Virtual Impactor (CVI) is described by Noone et al. (1988). The CVI had a $5 \mathrm{~L} \mathrm{~min}^{-1}$ sampling rate and a lower cutoff collection diameter of $5 \mu \mathrm{m}$. When flying through cloud the probe collected a large proportion of water droplets but not the interstitial aerosol. The water droplets were rapidly evaporated and the resulting residuals either collected on filters for post-flight, singleparticle analysis or measured by a Particle Measuring System's (PMS) Passive Cavity Aerosol Spectrometer Probe (PCASP) and a TSI 3010 condensation nucleus $(\mathrm{CN})$ counter. The $\mathrm{C}-131 \mathrm{~A}$ also carried instrumentation for fast characterization of fine-particle size distributions, using both a radially classified aerosol detector (RCAD) (Zhang et al. (1995) and a high-flow, high- 
efficiency condensation nucleus counter (Russell et al. 1995). The RCAD measures the concentration of mobility-classified aerosol in the diameter range 5-200 nm (Russell et al. 1996). Each distribution is characterized by 36 channels of data and requires $1 \mathrm{~min}$ for analysis. The resulting measurements aboard the C-131A provided unprecedented spatial resolution of submicron aerosol size distributions.

Size-segregated atmospheric aerosol composition was studied aboard the MRF C-130 using a volatility technique (O'Dowd and Smith 1993), in which the aerosol sample is passed through one of four heated tubes, each one preset to a different temperature $\left(40^{\circ}, 80^{\circ}, 150^{\circ}\right.$, and $\left.340^{\circ} \mathrm{C}\right)$. The heated aerosol is then sized $(0.1-3.0-$ $\mu \mathrm{m}$ diameter) and counted by a PMS Active Scattering Aerosol Spectrometer Probe (ASASP-X). This system is able to distinguish ammonium sulfate and sulfuric acid by evaporating these species at $100^{\circ}$ and $200^{\circ} \mathrm{C}$, respectively. The aerosol remaining after heating to over $300^{\circ} \mathrm{C}$ is assumed to be sea salt, which has been shown to be the case in conditions typical of the marine environment (O'Dowd and Smith 1993). Generally, the only other nonvolatile aerosol species in the measured size range is soot, but the number and mass concentrations of soot are too low in maritime air to make any significant impact on the residual size distribution.

Sampling of the ship stack emissions was not conducted due to constraints on resources. The analysis of aerosol properties relied on expected emissions from engine analysis studies done by the shipping industry. These results are described in Hobbs et al. (2000).

The National Oceanic and Atmospheric Administration (NOAA) polar-orbiting satellites were the primary space platforms used for observations of ship tracks during MAST. Cloud tracks produced by ships appeared most prominently in imagery from the 3.7- $\mu$ m channels on the NOAA-9, NOAA-11, and NOAA-12 satellites, which provided both morning and afternoon overpasses of the experimental area. Also, half-hourly observations of cloud conditions were available from visible and infrared imagery from the Geostationary Operational Environmental Satellite geostationary satellite.

\section{b. Procedure}

The MAST field operations were coordinated from an operations center at the Naval Postgraduate School in Monterey, California. The aircraft were directed, both before take off and during flight, to the cloud areas that either contained ship tracks or where MAST dedicated ships were performing maneuvers. On most occasions the aircraft then used radar to locate the largest ships in that area. On finding a suitable ship, the orientation of the plume from the ship was calculated using the ship's relative velocity and the mean wind velocity in the boundary layer. Straight and level runs were flown in the boundary layer perpendicular to the ship's plume so that the plume and the background air could be well sampled. Several of these runs were carried out both at different heights in the boundary layer and at distances up to $150 \mathrm{~km}$ downwind from the ship. In particular, attempts were made to locate where the plume first entered the base of the overlying stratus and stratocumulus clouds in order to sample the initial formation of the cloud track and the resulting cloud microphysical changes. Profiles through the boundary layer and the lower free troposphere were also flown close to the ship so that the thermodynamic and dynamic structure of the boundary layer could be ascertained.

On nine days during the experiment, dedicated navy ships were used. On most of these days the ships followed prescribed tracks, generally oriented upwind and downwind, in joint operations with the aircraft and the research vessel. The ships included diesel, steam turbine, gas turbine, and nuclear-powered propulsion systems, in order to help identify the processes involved in ship track formation. Several of the ship tracks produced by these ships were monitored over multiple satellite overpasses.

The plumes and ship tracks from 29 commercial ships of opportunity were investigated during MAST. All but one of these ships were identified, either by visual sightings from the aircraft or by radio contact.

\section{Overview of data}

Table 1 summarizes the ships that were studied during MAST; more detailed information is given by Hobbs et al. (2000). In all, 42 ships were encountered and exactly half of them produced a ship track while measurements were being made around them. Hobbs et al. (2000) show that diesel-powered ships burning low-grade fuel emitted the largest particles. All the diesel-powered ships except the USS Safeguard were burning low-grade marine fuel oil. As can be seen from Table 1, diesel-powered ships were most likely to produce a ship track. Although the Safeguard was burning cleaner fuel than other diesels and produced smaller particles, it did produce a ship track in conditions of very low background droplet concentrations on 13 June $\left(\sim 10-40 \mathrm{~cm}^{-3}\right)$. Durkee et al. (2000a) also showed that although steam turbine ships can produce ship tracks, they are significantly less likely to produce a track than diesel ships.

Data from 62 transects of cloud tracks carried out by the MRF C-130 and UW C-131A aircraft are shown in Figs. 1a and 1b. Figure 1a is a histogram showing the frequency of occurrence of various differences in the cloud drop effective radius between a ship track and the ambient cloud. Figure $1 \mathrm{~b}$ is a corresponding histogram for the percentage increase in droplet concentration in ship tracks compared to the ambient cloud. These data show that, on average, droplet radii were smaller by 3.5 $\mu \mathrm{m}$ and droplet concentrations were greater by $100 \%$ in the ship tracks than in the ambient clouds. The distributions also show that, under some combinations of ship propulsion properties and environmental condi- 
TABLE 1. Ships and propulsion type investigate during C-131A and C-130 flights during MAST. Occurrence of a ship track is also noted.

\begin{tabular}{|c|c|c|c|c|}
\hline Date, 1994 & Ship's name & $\begin{array}{l}\text { Propulsion } \\
\text { type }\end{array}$ & $\begin{array}{l}\text { Investigating } \\
\text { platform }\end{array}$ & $\begin{array}{c}\text { Ship track } \\
\text { observed }\end{array}$ \\
\hline 1 Jun & $\begin{array}{l}\text { Monterrey } \\
\text { Sierra Madre } \\
\mathrm{Pu} \mathrm{He}\end{array}$ & $\begin{array}{l}\text { Diesel } \\
\text { Steam turbine } \\
\text { Diesel }\end{array}$ & $\begin{array}{l}\text { UW C-131A } \\
\text { UW C-131A } \\
\text { UW C-131A }\end{array}$ & $\begin{array}{l}\text { Yes* } \\
\text { Yes* } \\
\text { Yes* }\end{array}$ \\
\hline 8 Jun & $\begin{array}{l}\text { Keystone Canyon } \\
\text { Fremo Scorpius } \\
\text { Samuel H Armacost } \\
\text { Hyundai Duke } \\
\text { USS Copeland }\end{array}$ & $\begin{array}{l}\text { Steam turbine } \\
\text { Diesel } \\
\text { Diesel } \\
\text { Diesel } \\
\text { Gas turbine }\end{array}$ & $\begin{array}{l}\text { MRF C-130 } \\
\text { UW C-131A } \\
\text { UW C-131A } \\
\text { MRF C-130 } \\
\text { Glorita }\end{array}$ & $\begin{array}{l}\text { Yes } \\
\text { Yes } \\
\text { Yes } \\
\text { Yes } \\
\text { No }\end{array}$ \\
\hline 9 Jun & $\begin{array}{l}\text { Newport Bridge } \\
\text { Evergreen Evergather } \\
\text { USS Copeland }\end{array}$ & $\begin{array}{l}\text { Diesel } \\
\text { Diesel } \\
\text { Gas turbine }\end{array}$ & $\begin{array}{l}\text { MRF C-130 } \\
\text { MRF C-130 } \\
\text { UW C-131A }\end{array}$ & $\begin{array}{l}\text { Yes } \\
\text { Yes } \\
\text { No }\end{array}$ \\
\hline 11 Jun & Brazilian Vitoria & Diesel & $\begin{array}{l}\text { MRF C-130 } \\
\text { UW C-131A }\end{array}$ & Yes \\
\hline 12 Jun & $\begin{array}{l}\text { Kurama } \\
\text { Skaugran } \\
\text { Moku Pahu } \\
\text { USS Safeguard }\end{array}$ & $\begin{array}{l}\text { Diesel } \\
\text { Diesel } \\
\text { Diesel } \\
\text { Diesel }\end{array}$ & $\begin{array}{l}\text { MRF C-130 } \\
\text { UW C-131A } \\
\text { UW C-131A } \\
\text { UW C-131A }\end{array}$ & $\begin{array}{l}\text { Yes } \\
\text { Yes } \\
\text { Yes } \\
\text { Yes }\end{array}$ \\
\hline 13 Jun & $\begin{array}{l}\text { Sanko Peace } \\
\text { USS Safeguard }\end{array}$ & $\begin{array}{l}\text { Diesel } \\
\text { Diesel }\end{array}$ & $\begin{array}{l}\text { MRF C-130 } \\
\text { MRF C-130 }\end{array}$ & $\begin{array}{l}\text { Yes } \\
\text { Yes }\end{array}$ \\
\hline 15 Jun & USS Abraham Lincoln & Nuclear & UW C-131A & No \\
\hline 16 Jun & $\begin{array}{l}\text { Direct Kookaburra } \\
\text { Research Vessel Glorita }\end{array}$ & $\begin{array}{l}\text { Diesel } \\
\text { Diesel }\end{array}$ & $\begin{array}{l}\text { MRF C-130 } \\
\text { MRF C-130 }\end{array}$ & $\begin{array}{l}\text { No } \\
\text { No }\end{array}$ \\
\hline 17 Jun & $\begin{array}{l}\text { Gold Bond Trailblazer } \\
\text { Bosphorus Bridge }\end{array}$ & $\begin{array}{l}\text { Diesel } \\
\text { Diesel }\end{array}$ & $\begin{array}{l}\text { Airship } \\
\text { MRF C-130 } \\
\text { UW C-131A }\end{array}$ & $\begin{array}{l}\text { No } \\
\text { No }\end{array}$ \\
\hline 19 Jun & Sea Pearl & Diesel & Airship & No \\
\hline $20 \mathrm{Jun}$ & $\begin{array}{l}\text { Unidentified ship } \\
\text { Glorita }\end{array}$ & Diesel & $\begin{array}{l}\text { Airship } \\
\text { Airship }\end{array}$ & $\begin{array}{l}\text { No } \\
\text { No }\end{array}$ \\
\hline $21 \mathrm{Jun}$ & $\begin{array}{l}\text { Cape May } \\
\text { USS Kansas City }\end{array}$ & $\begin{array}{l}\text { Diesel } \\
\text { Steam turbine }\end{array}$ & $\begin{array}{l}\text { MRF C-130 } \\
\text { MRF C-130 } \\
\text { UW C-131A }\end{array}$ & $\begin{array}{l}\text { Yes } \\
\text { No }\end{array}$ \\
\hline $\begin{array}{l}22 \text { Jun } \\
26 \text { Jun }\end{array}$ & $\begin{array}{l}\text { USS Kansas City } \\
\text { Mathilde Maersk }\end{array}$ & $\begin{array}{l}\text { Steam turbine } \\
\text { Diesel }\end{array}$ & $\begin{array}{l}\text { Glorita } \\
\text { Airship }\end{array}$ & $\begin{array}{l}\text { No } \\
\text { No }\end{array}$ \\
\hline 27 Jun & $\begin{array}{l}\text { Axel Maersk } \\
\text { Tai He } \\
\text { USS Mount Vernon }\end{array}$ & $\begin{array}{l}\text { Diesel } \\
\text { Diesel } \\
\text { Steam turbine }\end{array}$ & $\begin{array}{l}\text { MRF C-130 } \\
\text { MRF C-130 } \\
\text { UW C-131A } \\
\text { UW C-131A }\end{array}$ & $\begin{array}{l}\text { Yes } \\
\text { Yes } \\
\text { No }\end{array}$ \\
\hline 28 Jun & $\begin{array}{l}\text { Evergreen Evergenius } \\
\text { Bremen Express } \\
\text { USS Mount Vernon } \\
\text { USS Truxtun }\end{array}$ & $\begin{array}{l}\text { Diesel } \\
\text { Diesel } \\
\text { Steam turbine } \\
\text { Nuclear }\end{array}$ & $\begin{array}{l}\text { MRF C-130 } \\
\text { Airship } \\
\text { UW C-131A Glorita } \\
\text { UW C-131A Glorita }\end{array}$ & $\begin{array}{l}\text { Yes } \\
\text { Yes } \\
\text { No } \\
\text { No }\end{array}$ \\
\hline 29 Jun & $\begin{array}{l}\text { Star Livorno } \\
\text { Hanjin Barcelona } \\
\text { USS Mount Vernon } \\
\text { USS Truxtun }\end{array}$ & $\begin{array}{l}\text { Diesel } \\
\text { Diesel } \\
\text { Steam turbine } \\
\text { Nuclear }\end{array}$ & $\begin{array}{l}\text { UW C-131A } \\
\text { MRF C-130 } \\
\text { UW C-131A } \\
\text { Airship } \\
\text { Airship }\end{array}$ & $\begin{array}{l}\text { Yes } \\
\text { Yes } \\
\text { No } \\
\text { No }\end{array}$ \\
\hline 30 Jun & NYK Sunrise & Diesel & UW C-131A & Yes \\
\hline
\end{tabular}

* Undifferentiated ship racks were observed from the combined plumes of these nearby ships.

tions, the cloud droplet effective radius can be decreased by more than $10 \mu \mathrm{m}$ and droplet concentration can be increased by a few hundred percent.

The discussion below describes observations and analysis that test the hypothesis that these modifications of cloud microphysical properties by ships are due to particles from ship stacks and/or are generated in the water wake behind ships.

\section{Hypothesis 1i-Ship stack particles}

A necessary requirement for the success of hypothesis $1 \mathrm{i}$ - that submicrometer aerosols emitted from the ship stack are responsible for the ship track phenomenonis that properties of the aerosol population from a ship stack must be identified that are clearly different from the ambient aerosol. We attempted to identify such sig- 


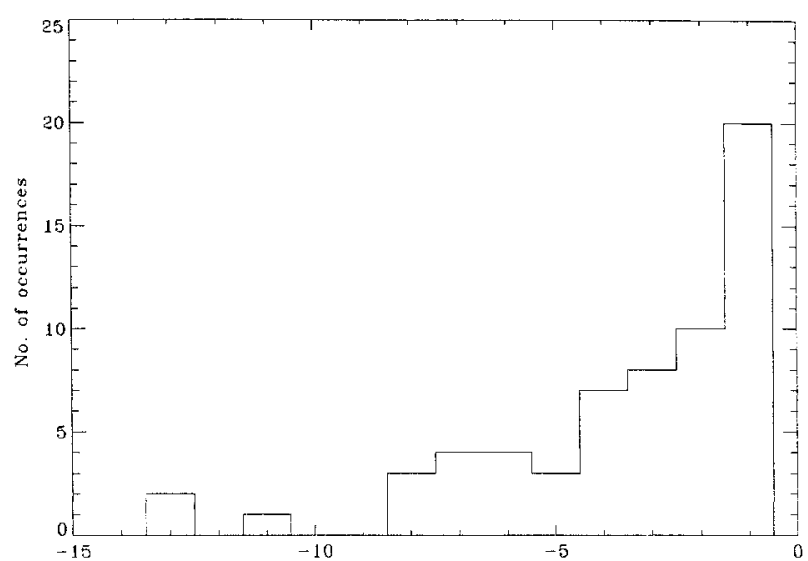

FIG. 1a. Histogram of effective radius differences $(\mu \mathrm{m})$ between ship track and ambient cloud (using FSSP and 2-DC data) from the C-131A and C-130 aircraft.

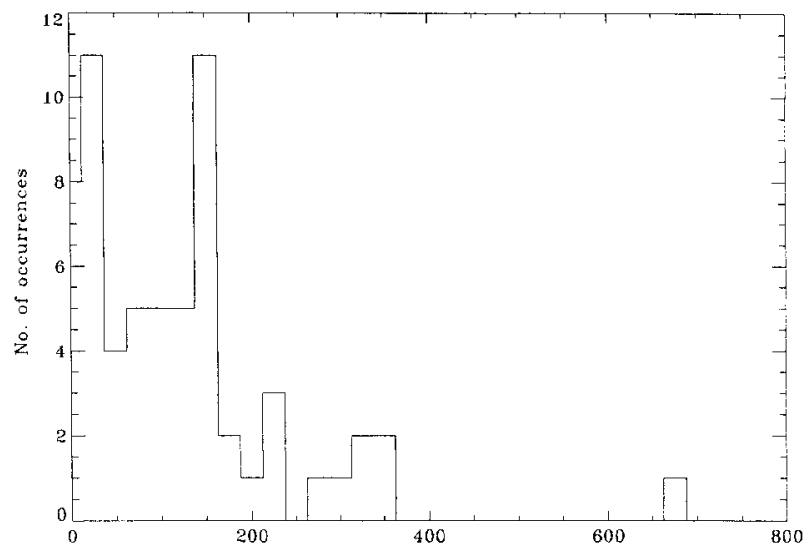

FIG. 1b. Histogram of increases (\%) in droplet concentration in ship tracks relative to ambient clouds from measurements made aboard C-131A and C-130 aircraft.

natures in MAST by examining the chemical and microphysical properties of the aerosol in and out of ship plumes. The hypothesis predicts that the number concentration of aerosol large enough to act as $\mathrm{CCN}$ should be significantly elevated above the background concentrations. Also, these aerosol are likely to be of different composition than the ambient particles in ways consistent with the production mechanisms of ship stack aerosol. If these properties are not observed, this would represent powerful negative evidence for the hypothesis.

\section{a. Microphysical evidence}

A number of different techniques were used to measure the microphysical characteristics of the aerosol during MAST. These were deployed on aircraft, the NRL airship and the R/V Glorita. Analyses of the microphysical datasets are presented below for cases of individual ship impacts on cloud properties.

\section{1) MicRopHySiCAL RESPONSE}

In all ship tracks observed in cloud during MAST, the increased cloud droplet concentrations were accompanied by substantial increases in interstitial aerosol number concentrations. These increases were most evident in continuous $\mathrm{CN}$ measurements, which served as a clear, near-real-time indication of a ship's plume. The size distribution measurements of the interstitial aerosol mimic this trend by also showing increased number concentrations of the interstitial aerosol within a ship track. However, concentration of $\mathrm{CN}$ was preferred because of the longer sampling time of the instruments used to measure aerosol size distributions (e.g., 30 s for RCADscanning electrical mobility spectrometer) and the increase in number concentrations provided by these instruments results from the average of the aerosol collected that hence include some effects of dilution from the ambient air.

The peak aerosol concentrations in the plumes from the Skaugran and Tai He occurred at $0.1-\mu \mathrm{m}$ diameter (dry). The average increase in concentration of the interstitial aerosol in the ship tracks was between $10 \%$ and $20 \%$, although in some cases the increase in number concentration was over $100 \%$. In the case of the Star Livorno, the increase in particle number concentration in the ship track, at the peak particle size of $0.06-\mu \mathrm{m}$ diameter (dry), exceeded a factor of 5. In addition, the peak in the ambient interstitial aerosol (at $0.03-\mu \mathrm{m}$ diameter) was significantly smaller than the in-track interstitial aerosol. The low aerosol concentrations present in the very clean ambient air on 29 June (JDT 180) make the increase in number concentration in the ship track obvious. In the case of the NYK Sunrise on June 30 , the background aerosol concentrations were higher, indicating more anthropogenic influence. In this case, there was very little shift in particle size; however, the interstitial particle concentrations in the ship track were about $50 \%$ higher than those in the surrounding ambient air.

On 13 June the C-130 studied a ship track produced by the Sanko Peace. Background cloud droplet concentrations, measured by the Forward Scattering Spectrometer Probe (FSSP), were among the lowest concentrations measured during MAST at between 12 and 25 $\mathrm{cm}^{-3}$. A run perpendicular to the ship track at a distance of approximately $20 \mathrm{~km}$ from the ship was flown 20$50 \mathrm{~m}$ below cloud top $(300 \mathrm{~m})$. Figure 2 shows a composite plot of the in-cloud aerosol, microphysical and cloud albedo measurements for this run. The droplet concentrations reached a peak value of $120 \mathrm{~cm}^{-3}$. The cloud droplet effective radius (ratio of the third moment of the size distribution to the second moment) decreased from $14 \mu \mathrm{m}$ in the ambient cloud to $8.5 \mu \mathrm{m}$ in the ship track. These observations were consistent with concentration and size variations at other altitudes. Large numbers of drizzle-sized drops were outside the measurement range of the $\operatorname{FSSP}(0.5-47-\mu \mathrm{m}$ diameter $)$. It is 

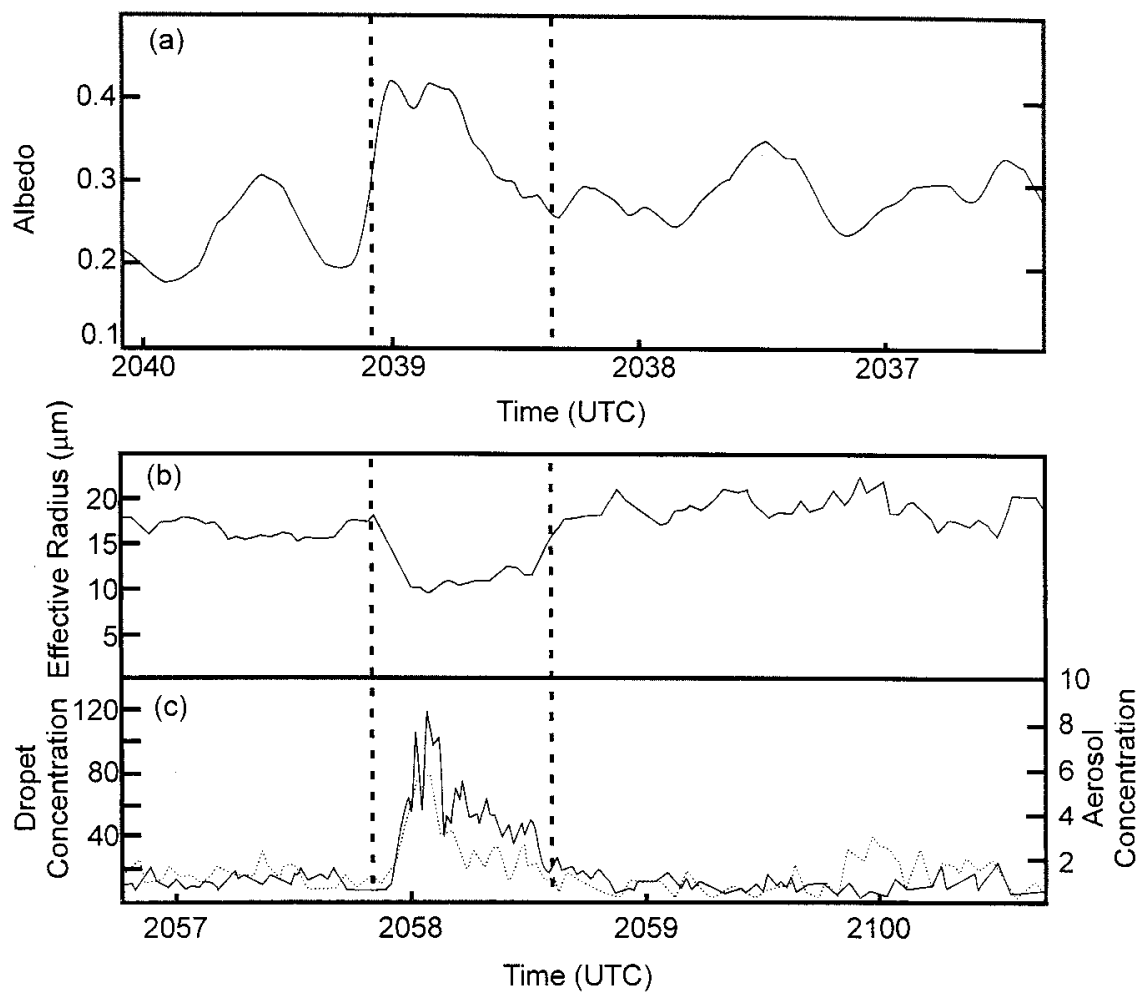

FIG. 2. Measurements from the C-130 of (a) albedo $(0.3-3.0 \mu \mathrm{m})$, (b) effective radius $(\mu \mathrm{m})$ from FSSP and 2D probes, and (c) droplet concentration from FSSP (solid line) and interstitial aerosol concentrations (dotted line) $\left(\mathrm{cm}^{-3}\right)$, across the ship track produced by the Sanko Peace on 13 Jun 1994. The ship track is between the vertical dashed lines. The albedo measurements were made about $20 \mathrm{~min}$ prior to the aircraft pass through the cloud at $20 \mathrm{~km}$ from the ship. (Note the $\mathrm{C}-130$ flies about $5 \mathrm{~km} \mathrm{~min}{ }^{-1}$ on measurement runs.)

therefore instructive to combine the measurements of the FSSP with those of the PMS 2D cloud probe, which measures in the diameter range 25-800 $\mu \mathrm{m}$. When this was done, a combined effective cloud droplet radius was computed and averaged over a 2 -s run in the cloud; the decrease in cloud droplet size in the ship track was found to be almost $50 \%$.

A run was made about $150 \mathrm{~m}$ above the cloud layer to determine its albedo. The albedo was derived by taking the ratio of the upwelling and downwelling irradiance measured by a pair of Eppley pyranometers that cover the spectral range $0.3-3.0 \mu \mathrm{m}$. A significant increase in albedo was observed across the ship track defined by the cloud microphysical measurements. On this occasion it was also noted that in the region of the ship track the cloud top was elevated by about $30 \mathrm{~m}$ above the background cloud. This dynamical response to the ship effects is not an expected effect due directly to microphysical changes. However, it is not inconsistent with a microphysical effect if radiative forcing by the albedo changes results in circulations that cause a lifting of the inversion layer.

On 29 June the C-130 studied the ship track produced by the Hanjin Barcelona. Figure 3 shows a composite plot of the data obtained during a series of runs below, in, and above the cloud layer at a distance of about 10 $\mathrm{km}$ from the ship. The age of the plume at this location was estimated to be around $30 \mathrm{~min}$. The lower panel of Fig. 3 shows the concentration of accumulation-mode aerosol (0.1-3.0- $\mu \mathrm{m}$ diameter), measured by the PCASP, as the aircraft crossed the plume beneath cloud base. The plume was about $1 \mathrm{~km}$ wide, and the aerosol concentration in the plume rose to in excess of 1000 $\mathrm{cm}^{-3}$, compared to about $75 \mathrm{~cm}^{-3}$ in the ambient air. This increase in aerosol concentration had a significant impact on the local cloud microphysics, as illustrated in the middle two panels of Fig. 3. The droplet concentration, measured by the FSSP, increased from a background value of 20 to $100 \mathrm{~cm}^{-3}$ in the ship track. It should be noted that the increase in droplet concentration was less than the increase in aerosol concentration below the cloud, indicating that a large fraction of the extra aerosol in the ship plume was not activated as CCN. During the in-cloud run, the LWC increased from around $0.15 \mathrm{~g} \mathrm{~kg}^{-1}$ in the ambient cloud to $0.27 \mathrm{~g} \mathrm{~kg}^{-1}$ in the ship track. The fivefold increase in droplet concentration, and moderate increase in LWC, resulted in a decrease in the cloud droplet effective radius by a factor of 0.77 (from around 9 to $7 \mu \mathrm{m}$ ). The effect of the reduced droplet effective radius and the increase in 


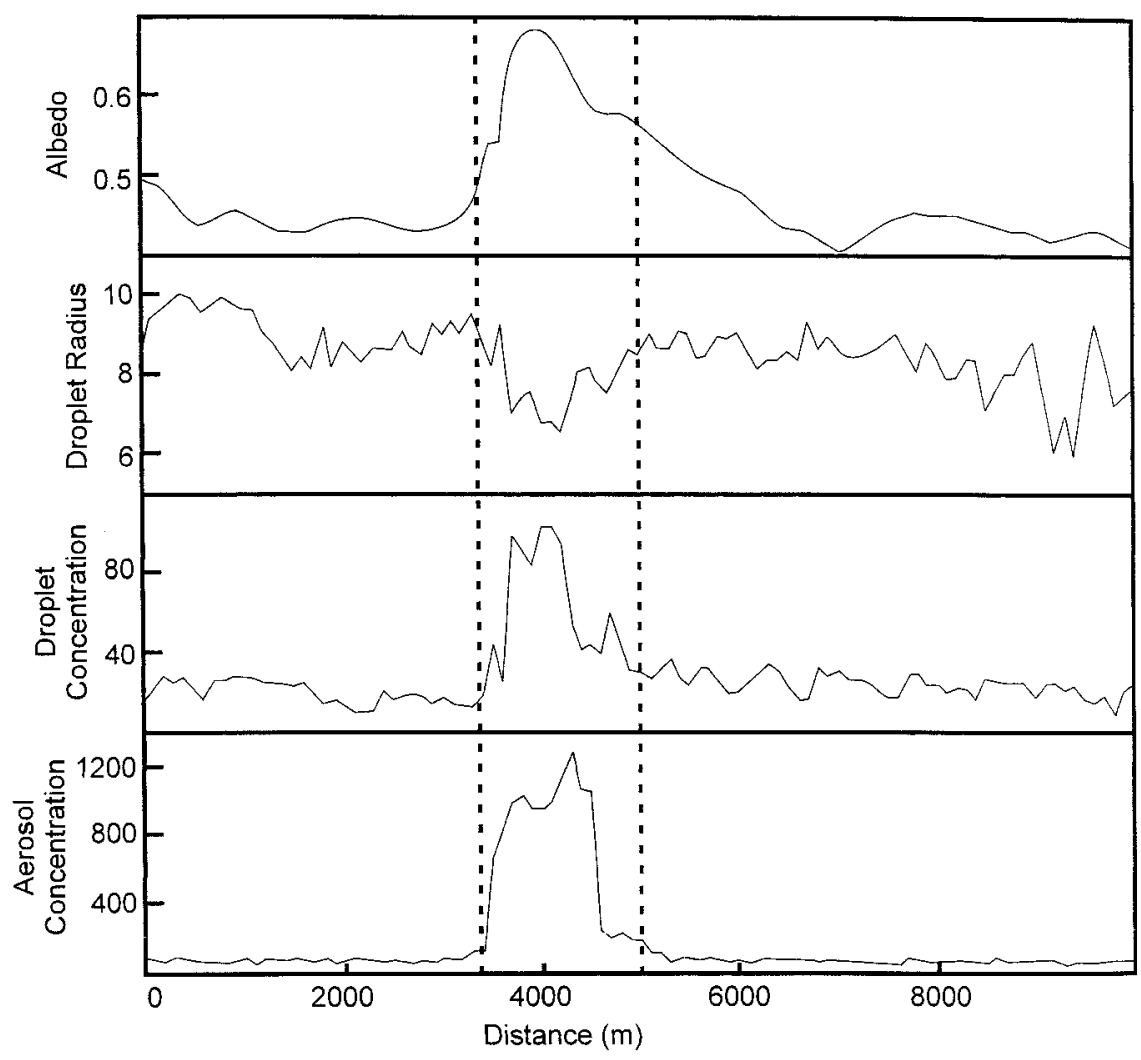

FIG. 3. Measurements made from the C-130 of albedo, cloud droplet radius $(\mu \mathrm{m})$, and droplet concentrations $\left(\mathrm{cm}^{-3}\right)$, and accumulation-mode aerosol concentrations across the ship track produced by the Hanjin Barcelona on 29 Jun 1994. The ship track is between the dashed vertical lines. The measurements were made about 30 min after emission from the ship.

LWC combined, in this case, to give a significant increase in the cloud albedo (for $\lambda=0.3-3.0 \mu \mathrm{m}$ ) as shown in the top panel of Fig. 3. Ship tracks do not consistently change background LWC although if change is detected it is usually increased. This suggests that the background environment is important in determining if change occurs. In this case, drizzle suppression by reduction of droplet size may be the cause. Ferek et al. (2000) address drizzle suppression and LWC changes in ship tracks.

These measurements provide strong evidence that ship tracks are produced by particles emitted from ship stacks. The higher numbers, and, in some cases, the larger sizes of the particles in ship plumes, compared to ambient air, indicate higher numbers of $\mathrm{CCN}$ available for activation to cloud droplets. The size of the major particle mode in both ship plumes (Hobbs et al. 2000) and in the interstitial cloud aerosol in ship tracks provides strong evidence that ship emissions are present in ship tracks. In addition, the speciation of organic compounds in droplets (Russell et al. 2000) and observations of volatile particles (possibly sulfates) in the plume aerosol (Noone et al. 2000b) collected in ship tracks indicates that aerosols produced by combustion emissions are present in the cloud droplets.
The airship sampled ship stack emissions quite close to several ships (Frick and Hoppel 2000). Most of the ships studied showed increased aerosol concentrations at all sizes between $0.005-$ and $0.6-\mu \mathrm{m}$ radius. Little difference was seen at radii larger than $0.5 \mu \mathrm{m}$. Frick and Hoppel conclude that only particles larger than about $0.05 \mu \mathrm{m}$ in radius emitted by the ships are likely to modify cloud properties.

Hobbs et al. (2000) summarizes the ship emissions studied in MAST. They found that diesel-powered ships burning low-grade marine fuel oil were the most likely to produce ship tracks. U.S. Navy vessels powered by steam turbines burning higher-grade fuel did not produce ship tracks. Commercial turbine-driven ships that burn marine fuel oil were observed to cause ship tracks in satellite imagery; however, the only such ship investigated during MAST (the Bremen Express) did not cause a ship track. Hobbs et al. conclude that fuel type, and the mode radius of the combustion aerosol, are important factors in determining whether or not a ship track is formed. Diesel-powered ships, burning marine fuel oil and marine distillate fuel, tend to emit particles with a mode radius between about 0.03 - and $0.05-\mu \mathrm{m}$ radius, while ships driven by steam turbines produce smaller particles (mode radius approximately $0.02 \mu \mathrm{m}$ ). These 


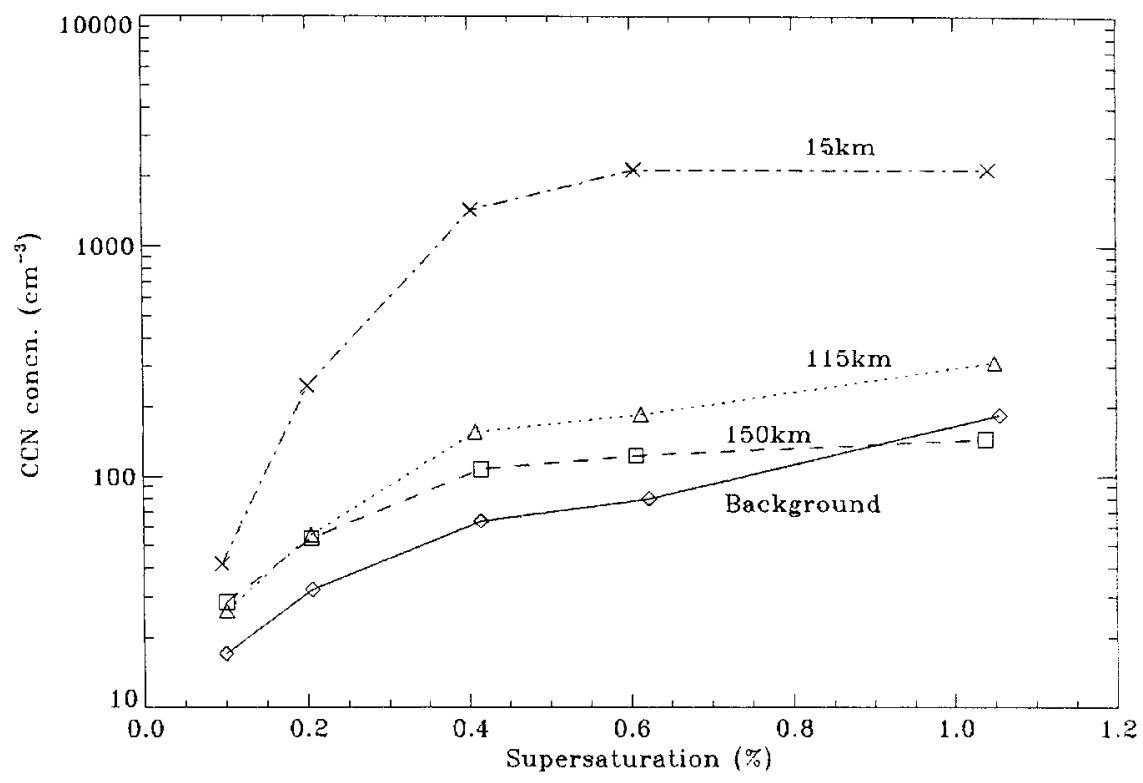

FIG. 4. CCN activity spectra showing number concentration vs supersaturation measured on the C-130 at various distances from the Hanjin Barcelona. The solid line is an average of observations in ambient conditions unaffected by the ship.

differences in mode radius result in factors of 5-10 in differences of $0.1-\mu \mathrm{m}$ radius particle concentrations because of the rapid decrease in number with particle size.

On 29 June the C-130 studied a ship track associated with the Hanjin Barcelona. Measurements were made in the boundary layer below cloud at several distances from the ship. An MRF thermal diffusion chamber was used to count CCN. Figure 4 shows a series of CCN activity spectra (i.e., number concentration of $\mathrm{CCN}$ vs supersaturation) measured at various distances from the ship. The measurements made in the ship's plume show a general decrease in $\mathrm{CCN}$ concentration, at any one supersaturation, with increasing distance from the ship.

The ambient droplet concentration measured by the C-130 approximately $10 \mathrm{~km}$ from the ship was $15-25$ $\mathrm{cm}^{-3}$. If it is assumed that the CCN concentration below cloud is equal to the droplet concentration in cloud, then we can use Fig. 4 to trace a concentration of $20 \mathrm{~cm}^{-3}$ across to the $\mathrm{CCN}$ spectra associated with the ambient cloud to find the critical supersaturation in the boundary layer cloud. This shows that in the ambient cloud the critical supersaturation was $0.1 \%-0.17 \%$. If we assume that this critical supersaturation was the same in the ship track, we can use the $\mathrm{CCN}$ activity spectra corresponding to a distance of $15 \mathrm{~km}$ from the ship (the nearest $\mathrm{CCN}$ activity spectra to the in-cloud measurements at $10 \mathrm{~km}$ from the ship). This procedure suggests that the droplet concentration should have increased to $70 \pm 30$ $\mathrm{cm}^{-3}$ in the ship track. The observed increase in droplet concentration was between 80 and $100 \mathrm{~cm}^{-3}$.

These data demonstrate that there is consistency between the observed changes in cloud droplet and CCN concentrations from the ambient air to the ship track associated with the Hanjin Barcelona. The assumption that the critical supersaturation was the same in the ambient cloud and in the ship track is a possible source of error in this analysis, since the supersaturation may be affected by ship effluents. Increased CCN concentration should tend to decrease supersaturation. Therefore, the observed droplet concentration appears somewhat higher than predicted by interpolation of the supersaturation spectrum in this case. However, the results are consistent with the hypothesis that an increase in aerosol concentration, resulting from a ship exhaust, can lead to an increase in CCN concentration, an increase in droplet concentration, a reduction in droplet size, and consequently an increase in the cloud albedo.

The background vertical velocity will also play a role in determining droplet number concentration. Figure 4 shows that within $15 \mathrm{~km}$ of the Hanjin Barcelona, increases in vertical velocity that results in increased critical supersaturation will cause more particles to become activated as cloud droplets. The effect is significantly stronger (greater slope) in the ship plume than in the ambient environment. Therefore, if vertical velocity is greater in the track relative to the ambient environment, the increase in droplet number will be enhanced by the combination of ship aerosol and greater critical supersaturation. This effect will have an impact on the magnitude of the droplet number enhancement within a ship track relative to ambient if the vertical velocity is different in the track compared to the environment. This may occur if radiative or dynamical forcing on the cloud generates differential circulations. The magnitude of the vertical velocity variations expected from these effects are not easily measured and were not within the capa- 
bility of the gust probe on the $\mathrm{C}-130$. Therefore, the significance of this effect must be addressed in future field measurements.

Hudson et al. (2000) presents an analysis of CCN measurements made aboard the UW C-131A. Excess droplet numbers in ship tracks relative to ambient cloud are shown to be consistent with $\mathrm{CCN}$ concentrations modified by plume dispersion down track. The analyses of Hudson et al. (2000) and Hobbs et al. (2000) indicate that about $10 \%-12 \%$ of particles emitted from a ship act as $\mathrm{CCN}$ at an effective supersaturation of $0.2 \%$. This suggests a large reservoir of unactivated particles, which through growth to accumulation mode sizes can replace any losses of CCN. This could be responsible for the long lifetimes of ship tracks although activation of droplets by other means cannot be ruled out.

\section{2) Quantitative LinKS}

To further test hypothesis $1 \mathrm{i}$ it is important to show that the microphysical processes described in hypotheses $1 \mathrm{i}$ and 1ii are quantitatively related to radiative changes in the cloud that can be detected as ship tracks in satellite imagery. Observations from 28 midcloud passes of the C-130 through seven ship tracks are compared to expected relationships between $\mathrm{CCN}$ concentration, droplet number concentration, droplet effective radius, and reflectance at 3.7- $\mu \mathrm{m}$ wavelength. For the purposes of this analysis, it is assumed that change in droplet number in the track compared to the ambient cloud is directly proportional to the change in $\mathrm{CCN}$ concentration. Hudson et al. (2000) show that this is generally true for four ship tracks observed by the C-131A. The average ratio of $\Delta \mathrm{CCN} / \Delta N_{d}$ for the four tracks was 1.1 -effectively unity given the uncertainties in the analysis.

The expected relationship between droplet number $\left(N_{d}\right)$ and effective radius $\left(r_{\text {eff }}\right)$ for constant liquid water volume can be expressed as

$$
\frac{\partial r_{\text {eff }}}{r_{\text {eff }}}=-\frac{1}{3} \frac{\partial N_{d}}{N_{d}} .
$$

That is, for a positive fractional change in droplet number, the expected fractional change in $r_{\text {eff }}$ would be negative and $1 / 3$ of the magnitude. The $1 / 3$ factor is a direct result of the relationship between volume and the cube of radius.

Correlations of fractional change of $r_{\text {eff }}$ and $N_{d}$ for the 28 passes of the $\mathrm{C}-130$ produce an average coefficient of -0.32 (with a standard deviation of 0.03 ) - well within the expected value of -0.33 . This result confirms that ship track induced changes in $r_{\text {eff }}$ are directly related to changes in droplet number.

The expected relationship between reflectance at 3.7$\mu \mathrm{m}$ wavelength and effective radius can be estimated from radiative transfer calculations. Figure 5 shows reflectance at 3.7- $\mu \mathrm{m}$ wavelength verses radius for three modified-gamma size distributions with widths defined

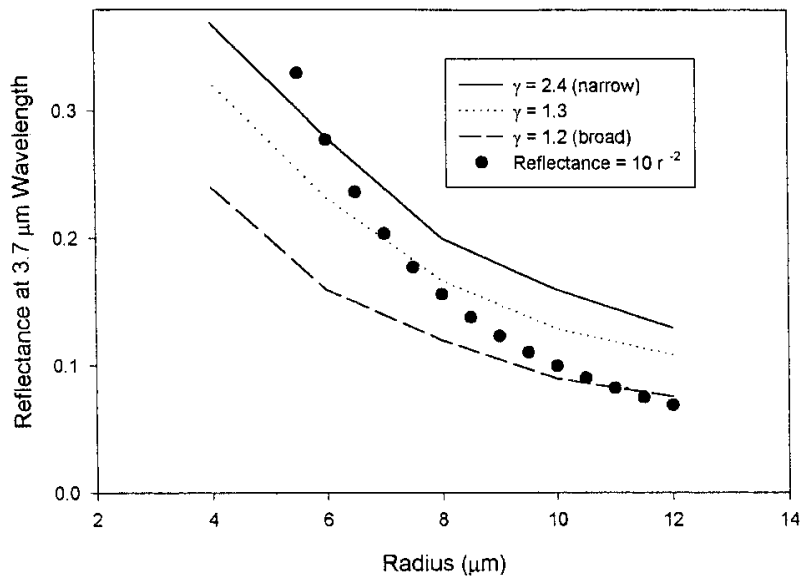

FIG. 5. Stratocumulus cloud reflectance at 3.7- $\mu \mathrm{m}$ wavelength for three droplet size distributions for a cloud $250 \mathrm{~m}$ thick and with a liquid water content of $0.4 \mathrm{~g} \mathrm{~m}^{-3}$. Reflectance was calculated by the delta-Eddington approximation for modified-gamma distributions of varying width $(\gamma=2.4,1.3$, and 1.2). Dots represent variation of reflectance by $r^{-2}$.

from narrowest to widest by $\gamma=2.4,1.3$, and 1.19 . Reflectance was estimated by a delta-Eddington reflectance model for a cloud $250 \mathrm{~m}$ thick and with a liquid water content of $0.4 \mathrm{~g} \mathrm{~m}^{-3}$.

Reflectance at $3.7-\mu \mathrm{m}$ wavelength was calculated from NOAA advanced very high resolution radiometer (AVHRR) imagery (following Mineart 1988) for coincident $r_{\text {eff }}$ observations. The correlation of reflectance at $3.7-\mu \mathrm{m}$ wavelength with effective radius for $18 \mathrm{com}-$ binations of satellite reflectance suggests a relationship of the form $\rho \propto r_{\text {eff }}^{-2}$. This function is plotted in Fig. 5 and shows that the function tends to cross the modeled curves from the narrow distribution at small radii to the broader distribution at larger radii. This is consistent with observations made in previous studies such as Mineart (1988) where droplet distributions tend to broaden as droplet size increases.

\section{b. Particle chemical signatures}

Several different approaches were used to determine the chemical composition of the aerosols in the boundary layer during MAST. Aerosol samples from cloudfree areas, as well as cloud interstitial aerosol, were collected from the UW C-131A. These samples were obtained by rapidly filling a $2.5-\mathrm{m}^{3}$ bag on the aircraft through an isokinetic inlet (Hobbs et al. 1991). The aerosol sampled in this way was collected on different substrates for subsequent chemical analysis.

A pair of Teflon filters was used to collect the aerosol for analysis of ionic composition. One of the Teflon filters collected all particles, and the other filter collected particles smaller than $3.5-\mu \mathrm{m}$ radius. The concentrations of the major ionic species were subsequently determined using ion chromatography. Hobbs et al. (2000) and Noone et al. $(2000 \mathrm{a}, \mathrm{b})$ examine the results from these 
filters and conclude that ship stack emissions do not have a substantial effect on the mass of the major ionic aerosol species in the ship plumes. An increase in sulfate (3-4 $\mu \mathrm{g} \mathrm{m}^{-3}$ within $10 \mathrm{~km}$ of the ship) above ambient values was observed in a single case (the NYK Sunrise on 30 June) during MAST (Hobbs et al. 2000).

Another set of filters was exposed for analysis of organic species in the aerosol (Russell et al. 2000). Outof-cloud and cloud interstitial aerosols were obtained using the bag sampler on the C-131A described above, and samples of cloud droplet residual particles were obtained using the counterflow virtual impactor (CVI). Russell et al. (2000) report that 2-10 times higher mass concentrations of some organic compounds were present in the ship plumes and in the interstitial aerosol samples in ship tracks than in any of the ambient below cloud or cloud interstitial samples. Due to short sampling times, no data from the CVI samples in ship tracks were available for the bulk organic species. However, analysis of cloud droplet residuals in the ambient clouds indicated that organic species were incorporated into cloud droplets. Since elevated levels of combustion-derived organic species were found in ship plumes, and in the interstitial aerosol in ship tracks, and since similar compounds were incorporated in cloud droplets in the ambient clouds, it seems likely that organic materials from ship effluents play a role in changing droplet concentrations and sizes in ship tracks. However, taken alone, the evidence on this point is not sufficiently strong to validate hypothesis $1 \mathrm{i}$.

If ship effluents are responsible for ship tracks, it is through their effects on CCN number concentrations rather than aerosol mass concentrations. Since the size range of particles that dominate the number and the mass of aerosols in the marine boundary layer is different, detecting a change in aerosol properties based on particle mass that can be directly related to an increase in the number of droplets in ship tracks is difficult. For this reason, a number-based chemical analysis of the aerosol was undertaken in MAST.

Single-particle analysis of cloud droplet residual particles in ship tracks and in ambient clouds, as well as of above-cloud, below-cloud, and ship-plume aerosol, was performed. Residual particles $>0.1-\mu \mathrm{m}$ radius were analyzed using an electron probe microanalysis technique (Xhoffer et al. 1992). Typically, 500 individual particles per sample were analyzed. Their elemental composition was determined and the results were classified into clusters of particles having similar chemical composition such as aged sulfate, sea-salt aerosol, and organic particles (Noone et al. 2000a,b).

The NYK Sunrise case on 30 June was particularly relevant to hypothesis 1i. Eight filter samples for singleparticle analysis were obtained on this day: a cloud residual particle sample from the NYK Sunrise, one from several ship tracks observed on the ferry out to the operations area, two ambient cloud residual samples, plume samples from the USS Copeland and NYK Sun- rise, as well as ambient aerosol samples above and below cloud. A subset of 500 individual particles was analyzed for each of these samples.

Ambient cloud residual particles on the ferry flight out, as well as on the cross-track legs far from the NYK Sunrise, show very similar compositions consisting of sea salt and a combination of sulfate and sea salt. Residual particles from cloud droplets collected in the ship track produced by the NYK Sunrise show the presence of an additional Si-containing component. This component was also found in the below-cloud plume sample from the NYK Sunrise, but in no other samples from this flight.

Silicon is a component of soil dust and fly ash. Silicon is also used in the manufacturing process for the marine distillate fuel used by ships such as the NYK Sunrise. Since none of the other samples on this day contained this component, it is unlikely that soil dust in the boundary layer, or entrained from the free troposphere, was the source of the silicon in the plume and ship track samples. Since the Si-containing component was only found in the ship track and ship-plume samples from the NYK Sunrise, it provides strong evidence linking stack emissions from the NYK Sunrise to the ship track. Interestingly, this component was not found in the plume sample from the Copeland (which did not produce a ship track), probably reflecting the different propulsion systems of the two ships.

\section{c. Ship track formation}

\section{1) INITIAL TRACK FORMATION}

The plume and ship track from the Hanjin Barcelona were investigated on 29 June by the MRF C-130 aircraft. The ship track was remarkable for its persistence and length. In this case the $\mathrm{C}-130$ aircraft was also able to sample the plume and cloud track very close to the point where the ship's plume first entered the stratocumulus cloud base. Some details of the measurements made in this region are given here.

The Hanjin Barcelona, which is powered by a diesel propulsion unit, was heading toward Long Beach, California, on a course of $118^{\circ}$ at 21 knots. An extensive sheet of stratocumulus, which had formed in a relatively clean maritime air mass that was being advected southeastward, covered the area. The cloud base was close to $500 \mathrm{~m}$, and cloud top was coincident with the top of the boundary layer, which was approximately $800 \mathrm{~m}$ deep and capped by a sharp temperature inversion (7 $\mathrm{K})$. The cloud cover varied between total and seveneighths. The background aerosol concentrations below cloud base were between 40 and $100 \mathrm{~cm}^{-3}$. The maximum LWC was about $0.7 \mathrm{~g} \mathrm{~kg}^{-1}$ and droplet concentrations were between 15 and $25 \mathrm{~cm}^{-3}$, which resulted in a relatively large peak effective cloud droplet radius of 12 to $13 \mu \mathrm{m}$. Several aircraft passes were made through the ship's plume at only $40-80 \mathrm{~m}$ above the 


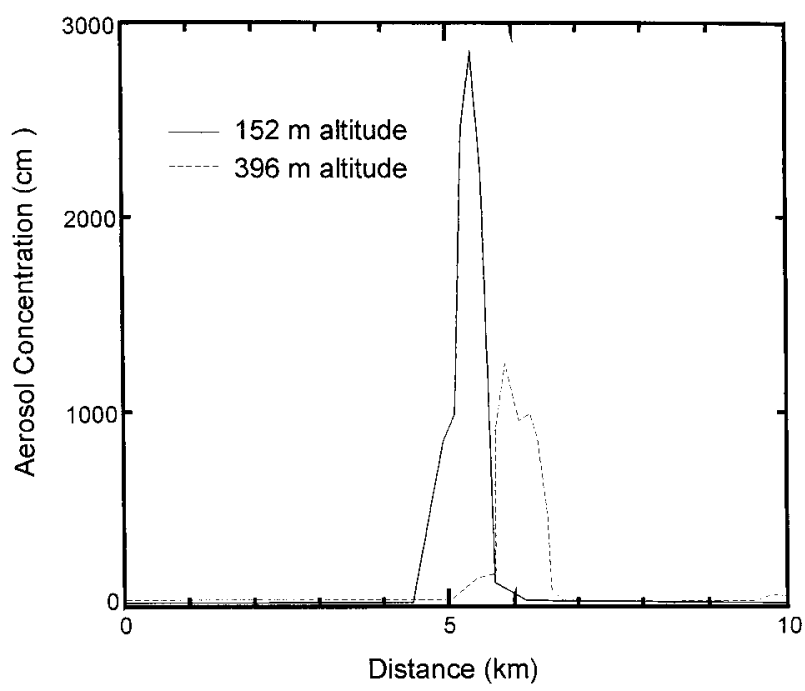

FIG. 6. C-130 measurements (PCASP) of aerosol concentration at 152- and 396-m altitude at $9 \mathrm{~km}$ from the Hanjin Barcelona. The offset of the two plumes results from advection of the plume between aircraft passes.

ship's stack. At this point, the plume was very narrow and aerosol concentrations in the accumulation mode were in excess of $15000 \mathrm{~cm}^{-3}$. The plume at this stage was visible to the naked eye. It was estimated that the plume reached cloud base at between 5 and $8 \mathrm{~km}$ from the ship, by which time the plume had dispersed to fill much of the depth of the boundary layer.

A series of runs at different altitudes in, and just above, the boundary layer were flown $9 \mathrm{~km}$ from the Hanjin Barcelona through the plume and perpendicular to its length. Figure 6 shows the PCASP measurements obtained at 152- and 396-m altitude. Underneath the cloud the plume was very narrow (approximately $1 \mathrm{~km}$ wide, which was about the depth of the boundary layer), and the aerosol concentrations had a "top hat" profile across the plume with very sharp boundaries. The penetrations of the plume made by the aircraft indicated that the aerosol concentrations were larger lower down in the boundary layer. At $152 \mathrm{~m}$ the maximum concentration recorded was $2880 \mathrm{~cm}^{-3}$, while at $396 \mathrm{~m}$ it decreased to $1300 \mathrm{~cm}^{-3}$. The impact of the ship's plume on the cloud microphysics was almost immediate once the plume entered cloud base. The peak droplet concentrations within the ship track were almost three times larger than those in the background cloud and, as a result, the effective radius of the cloud droplets was diminished by $2.5 \mu \mathrm{m}$. This rapid change in cloud microphysics had a significant effect on the radiative transfer characteristics of the cloud. The cloud albedo (from $\lambda=0.3-3.0 \mu \mathrm{m}$ ), as measured by the aircraft from above the cloud, increased from 0.45 for the ambient air cloud to 0.7 for the ship track. As a result of the additional solar radiation reflected by the ship track, the downwelling irradiance measured below the cloud was almost $300 \mathrm{~W} \mathrm{~m}^{-2}$ less beneath the ship track than beneath the ambient cloud.

This case is typical of many of the MAST studies, in that changes in the cloud microphysics associated with the ship track were well correlated with the penetration of the ship's plume into cloud base. Ships that did not produce plumes containing particles large enough to serve as $\mathrm{CCN}$ produced no observable ship tracks (Hobbs et al. 2000).

\section{2) DIESEL- VERSUS STEAM TURBINE-POWERED SHIPS}

Hudson et al. (2000) discuss the effects of engine and fuel type on $\mathrm{CCN}$ production. The efficiency of $\mathrm{CCN}$ production relative to total particle production is $6-10$ times higher for diesel ships burning marine fuel oil than for steam and gas turbines using navy distillate fuel. This appears to be the most likely explanation for the relative inability of U.S. Navy ships to produce ship tracks in the conditions encountered during MAST.

Noone et al. (2000b) examined a case where two ships in the same air mass and cloud condition were investigated. On 27 June the COSCO Tai He (36 000 ton, $17 \mathrm{MW}$, diesel propulsion) caused a ship track and the USS Mt. Vernon (13 700 ton, 17.9 MW, steam turbine) did not. The background cloud droplet concentrations were $70-100 \mathrm{~cm}^{-3}$ for both ship tracks. Perhaps the most important difference between the two cases, in terms of ship track formation, was the size of the submicrometer aerosol from the ships. The Tai He produced substantial numbers of particles with radii between 0.01 and 0.1 $\mu \mathrm{m}$, while the $M t$. Vernon produced particles generally smaller than $0.03-\mu \mathrm{m}$ radius. The fact that the larger particles (accumulation-mode particles and particles down to circa $0.03-0.04-\mu \mathrm{m}$ radius) produced by the Tai He were able to form additional cloud droplets in the tracks was supported by the significantly higher $\mathrm{CCN} / \mathrm{CN}$ ratio observed in the Tai He plume (3.7 \pm 1.3) compared to the Mt. Vernon plume (1.2 \pm 0.9$)$ (Hudson et al. 2000). In addition, Durkee et al. (2000a) in a statistical analysis of ship track formation show that, compared to diesel ships, steam-turbine ships produce fewer ship tracks, and those they produce have a significantly smaller enhancement of cloud reflectance. These results are strong evidence in support of MAST hypothesis $1 \mathrm{i}$.

\section{3) COMPARISON OF A DIESEL-POWERED SHIP WITH A NUCLEAR-POWERED SHIP}

The USS Truxtun, a nuclear cruiser, operated as part of MAST on 28-29 June. On 28 June the Truxtun operated in coordination with the steam turbine-powered USS Mt. Vernon and in the vicinity of several dieselpowered ships. In satellite imagery collected during these operations, neither the Truxtun nor the Mt. Vernon produced ship tracks, while all of the known merchant 


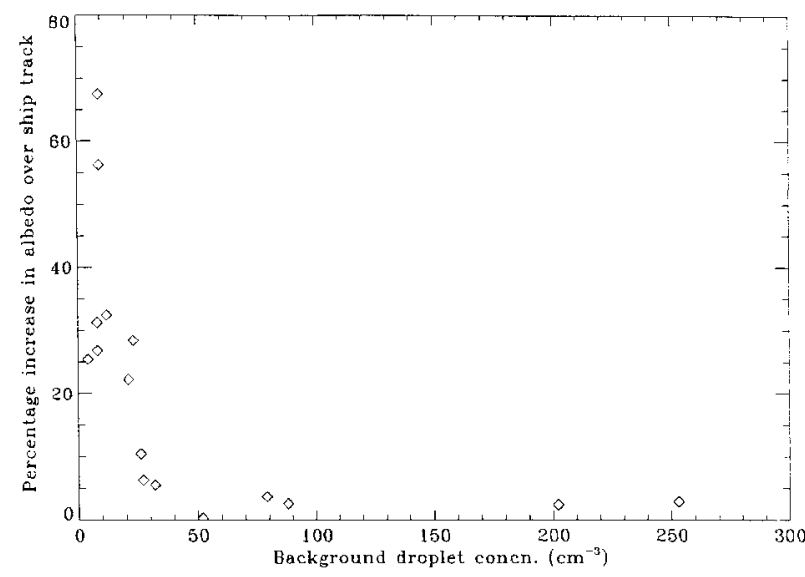

FIG. 7. Percentage increase (relative to ambient clouds) in albedo over ship tracks vs ambient droplet concentrations. Composite observations from six C-130 flights.

diesel ships in the area produced strong ship tracks. This exercise was designed as a test of hypothesis $1 \mathrm{i}$ but failed as a direct test since neither ship produced a track. Certainly, if the nuclear-powered Truxtun had produced a ship track, hypothesis $1 \mathrm{i}$ would have been negated. However, since merchant ships in the area produced tracks, including the diesel-powered Ever Genius, it appears that diesel-powered ships are more effective track producers than steam- or nuclear-powered ships. In view of the results described by Hobbs et al. (2000) and Hudson et al. (2000), it is not surprising that the Mt. Vernon did not produce a ship track, since steam turbine emissions are 6-10 times weaker sources of $\mathrm{CCN}$ than dieselpowered merchant diesels.

\section{4) EFFECT OF BACKGROUND CONDITIONS ON CLOUD TRACK FORMATION}

The relative brightness of ship tracks compared to their ambient clouds was found to be very dependent on the albedo of the ambient clouds which, in turn, depended on how much pollution was in the boundary layer. The brightest ship tracks were always observed when the boundary layer was relatively clean. Case studies with markedly different background pollution are described in this special issue. Noone et al. (2000a) show that the ship tracks produced by the Kurama and the Brazilian Vitoria, in a highly polluted boundary layer, were extremely difficult to detect using aircraft instrumentation, because the changes in cloud drop effective radius and concentration were very small and close to the natural background variations. Noone et al. (2000b) show that a much weaker cloud track was formed by the Cosco Taihe in a moderately polluted boundary layer.

Figure 7 shows results from six flights of the MRF C-130, which illustrate how the difference between cloud drop effective radius in ship tracks and the background cloud depends on the cloud susceptibility (Plat- nick et al. 2000; Taylor et al. 2000). The ship tracks were identified from observations of significant increases in droplet concentrations observed during an aircraft run in cloud. The runs in cloud were flown in succession to minimize errors associated with cloud evolution. The percentage increase in cloud albedo in passing from above the ambient cloud to over the ship track is plotted against the corresponding ambient cloud droplet concentration in Fig. 7. On several occasions no increases in either droplet concentration or albedo were observed, but these points are omitted from Fig. 7. The data presented show clearly that the impact of a ship track on cloud albedo is a strong function of the ambient cloud droplet concentration. In clouds with moderately high droplet concentrations the change in albedo associated with the reduced droplet size in the plume is small, since the albedo of these clouds was already high and hence their susceptibility to further change in albedo was low. For low ambient cloud droplet concentrations the increase in albedo was often quite dramatic, with one case exhibiting a $67 \%$ increase.

It is possible that background droplet concentration could be correlated with environmental conditions that affect ship track formation such as boundary layer depth, and this could explain some of the correlation in Fig. 7. However, no significant differences in environmental conditions were noted between those cases with high and low background droplet concentrations.

The observations summarized in this section show that it is the aerosol perturbation that ships produce in the marine boundary layer that is responsible for the formation of ship tracks and the associated change in cloud reflectivity, and therefore that hypothesis $1 \mathrm{i}$ is correct. The strength of a ship track and therefore the ability of aircraft to measure and satellites to detect a ship track are very dependent on the ambient levels of pollution. The lower the ambient pollution, the more susceptible are the clouds to ship track formation.

\section{d. Modeling results}

Comparison of observations and measurements with numerical model simulations of ship tracks can provide some insights into the microphysical processes involved. The Science Applications International Corporation model combines a Lagrangian stochastic plume evolution model with a simple microphysics model of the Twomey type. The model assumes that ship tracks are due entirely to cloud microphysical changes produced by the introduction of additional $\mathrm{CN}$ into the cloud. The microphysics model predicts cloud droplet concentrations according to the equation

$$
N=C_{1}\left(d_{1} S^{*}\right)^{k_{1}}+C_{2}\left(d_{2} S^{*}\right)^{k_{2}},
$$

where $N$ is the droplet concentration; $C_{1}$ and $C_{2}$ are the $\mathrm{CN}$ concentrations of the ambient atmosphere and ship plume, respectively; and $k_{1}$ and $k_{2}$ are exponents that are chosen to describe the ambient and plume activity 
spectra over a range of supersaturation, $S^{*}$, present within the cloud. The coefficients $d_{1}$ and $d_{2}$ are chosen so that the equation reproduces the activation ratio of $\mathrm{CN}$ to $\mathrm{CCN}$ at a representative value of $S^{*}$ (less than $1 \%$ ) within the cloud. For validation purposes, $C_{1}$ and $C_{2}$ are taken to be the aircraft measured PCASP concentrations and $N$ is taken to be the FSSP concentration measured from an aircraft. The supersaturation depends on the $\mathrm{CN}$ count, the exponents $k_{1}$ and $k_{2}$, temperature, and pressure. In essence, as the $\mathrm{CN}$ count increases upon introduction of plume aerosols, condensation occurs, which lowers $S^{*}$ and decreases the overall percentage of $\mathrm{CN}$ that become $\mathrm{CCN}$.

This model was used to simulate the ship track produced by Fremo Scorpius on 8 June. The UW C-131A aircraft made measurements of the ship track in the vicinity of the Hyundai Duke and the C-130 This case was chosen because the UW C-131A made detailed measurements of the $\mathrm{CCN}$ activity spectrum, the $\mathrm{CN}$ flux rate from the ship, and the $\mathrm{CN}$ and $\mathrm{CCN}$ concentrations. The Lagrangian stochastic code was initialized using the measured flux rate and values of $k_{2}$ and $d_{2}$, which were a close fit to the plume activity spectrum over the range $0.2 \%<S^{*}<0.4 \%\left(k_{2}=1.68, d_{2}=\right.$ 1.54). The boundary layer was assumed to be well mixed, and the turbulence was an approximate fit to data collected nearby from the MRF C-130. Simulations were made both with a cold plume (i.e., no heat perturbation) and with nearly the maximum waste heat expected from the ship.

The observed boundary layer depth was $300 \mathrm{~m}$ with cloud bases at $130 \mathrm{~m}$. Droplet number increased in the track from $70 \mathrm{~cm}^{-3}$ in the ambient cloud to $150 \mathrm{~cm}^{-3}$ in the ship track. This increase was consistent with the observed change in effective radius from $9 \mu \mathrm{m}$ (ambient) to 4-6 $\mu \mathrm{m}$ (track). The model predictions of $\mathrm{CN}$ compared to PCASP measurements, and CCN compared to FSSP measurements, were very good. Additionally, for this case, there was no significant difference between the heated and unheated plumes beyond approximately $8 \mathrm{~km}$ downwind. Therefore, heat is expected to have an ancillary effect, possibly lifting the plume through a decoupled or deep boundary layer, but otherwise usually not significantly impacting the droplet density within the cloud track beyond a few kilometers downwind. The results from these model simulations, although not conclusive, support hypothesis $1 \mathrm{i}$.

\section{Hypothesis 1ii-Wake particles}

It has long been known that sea-salt aerosols are produced at the ocean surface by winds and waves, primarily by bubble bursting (Blanchard and Woodcock 1980). Salt particles produced by this mechanism generally dominate the mass of marine aerosol above about $0.5-\mu \mathrm{m}$ radius but amount to only a few percent of the number concentration, which is dominated by submicron sulfates produced via gas-to-particle conversion.
Sea-salt aerosol concentrations show a fairly good correlation with wind speed (O'Dowd and Smith 1993; Andreae 1995; Hoppel and Frick 1990) but generally amount to a few tens of particles per cubic centimeter or less, which is characteristic of most mechanical generation mechanisms that produce coarse particles. Since ships are capable of producing vast quantities of bubbles in their turbulent wakes, enough salt particles might be generated and transported to cloud level to produce a ship track, either by supplementing the aerosols emitted from ship stacks, or in the case of a nuclear-powered ship, in the absence of particles emitted from the ship's stack.

Several types of measurements were employed in MAST to investigate this possibility. In a previous study of two ship tracks off the U.S. Pacific Northwest coast, no evidence of significant increases of sea salt was found in either filter samples of ship plume particles or samples of cloud water in ship tracks (Ferek et al. 1998). Similarly, in virtually every case during MAST, no evidence could be found for a significant above-ambient salt component in either the filter samples, aerosol size distributions, or in the salt-particle size distributions. A few of the many available examples are discussed below to illustrate this conclusion.

Numerous aerosol size distributions were measured during MAST in ship plumes and nearby ambient conditions. These distributions consistently indicate that, above $0.2-\mu \mathrm{m}$ radius (where mechanically generated sea-salt particles would be expected), plume particles compared with similarly sized particles in ambient air near the ships show no significant differences (Hobbs et al. 2000). Sea-salt particles generated in a ship wake are far too few in number to have a significant impact on the number of CCN transported to cloud level, compared to the large number of particles attributed to emissions from a ship stack.

On 15 June the aircraft carrier USS Abraham Lincoln, one of the largest nuclear-powered vessels in the U.S. Navy, passed through the MAST operations area under cloud-free conditions at a speed of about 30 knots heading directly into the prevailing wind. A long white bubble wake was observed extending for approximately 2 $\mathrm{km}$ behind the ship. As such, this ship was expected to be our best opportunity for detecting a wake-generated sea salt plume. In several passes by the UW C-131A at an altitude of $500 \mathrm{ft}$ about 5 miles behind the ship, a distinct particle plume was observed with the $\mathrm{CN}$ counters (possibly due to helicopter operations that were being conducted on the flight deck). Two pairs of filter samples were collected with the grab-bag in these particle plumes. Analysis of these collections show that, although there was slightly more sea salt measured by the total filters compared to the filters preceded by the cyclone, there was no significant difference between salt concentrations in the plume and the ambient air. Similar filter measurements made in the plumes from all of the 
other ships sampled during MAST also showed no enhancement in sea salt.

These results show that, on average, there was no significantly enhanced sodium or chloride in the plumes from ships compared to similar measurements in the ambient air. Comparison of the total filter results to the filters proceeded by the cyclone show that $85 \%$ of the sea salt resided in particles $<3.5 \mu \mathrm{m}$. For all 90 filters collected during the MAST study, the sodium-to-chloride ratio averaged 0.66 , compared to the seawater ratio of 0.56 , indicative of a slightly aged sea-salt aerosol somewhat depleted in chloride. This is likely due to the addition of acidic products of the gas-to-particle conversion of $\mathrm{SO}_{2}$ and $\mathrm{NO}_{x}$, rather than to a fresh sea-salt aerosol that would more closely reflect the seawater ratio.

Measurements by the sodium particle size spectrometer also failed to detect enhanced salt-containing particles in the plumes from all the ships studied by the C-131A. On several occasions, including the flight near the Abraham Lincoln, the salt counter was operated in the continuous-sampling mode during passes behind ships; at no time was an increase in the number concentration of salt particles observed when the plumes were penetrated.

Similarly, aerosol volatility measurements made on the MRF C-130 showed no significant sea-salt perturbations in the ship's plume at any time during the MAST experiment. Figure 8 shows a typical example of the aerosol volatility characteristics in and out of the ship's plume. This example was from the plume of the Kurama on 11 June (Noone et al. 2000a), from measurements at $170-\mathrm{m}$ altitude (below cloud base) and $28 \mathrm{~km}$ from the ship. The boundary layer was $500 \mathrm{~m}$ deep and very well mixed throughout. The measurements imply that the ambient aerosol was made up of internally mixed ammonium sulfate and sulfuric acid particles in concentration of $\sim 150 \mathrm{~cm}^{-3}$, and a sea-salt contribution of approximately $20 \mathrm{~cm}^{-3}$. The in-plume measurements show almost identical sea-salt $\left(340^{\circ} \mathrm{C}\right)$ and ammonium sulfate $\left(150^{\circ} \mathrm{C}\right)$ distributions as in the ambient air, indicating that the ship produced no significant perturbation of these aerosol species.

On the 29 June the NRL airship made measurements over the water wake of the USS Truxtun at altitudes of less than $50 \mathrm{~m}$. Since the Truxtun is a nuclear-powered ship it had no observable engine exhaust plume. Measurements taken at an altitude of $25 \mathrm{~m}$ show only a slight (statistically insignificant) increase in particle concentration upwind of the wake $\left(15.6 \mathrm{~cm}^{-3}\right) \mathrm{com}-$ pared to downwind of the wake $\left(18.1 \mathrm{~cm}^{-3}\right)$. The pilot attempted to maintain a constant altitude, but postflight analysis indicated that the measurements on the downwind side were more typically at about $35 \mathrm{~m}$ in altitude. The differences in concentration can be explained by the higher humidity at this altitude causing the growth of aerosol particles into the size range of the instrument. On this particular day, the ambient wind was $15 \mathrm{~m} \mathrm{~s}^{-1}$
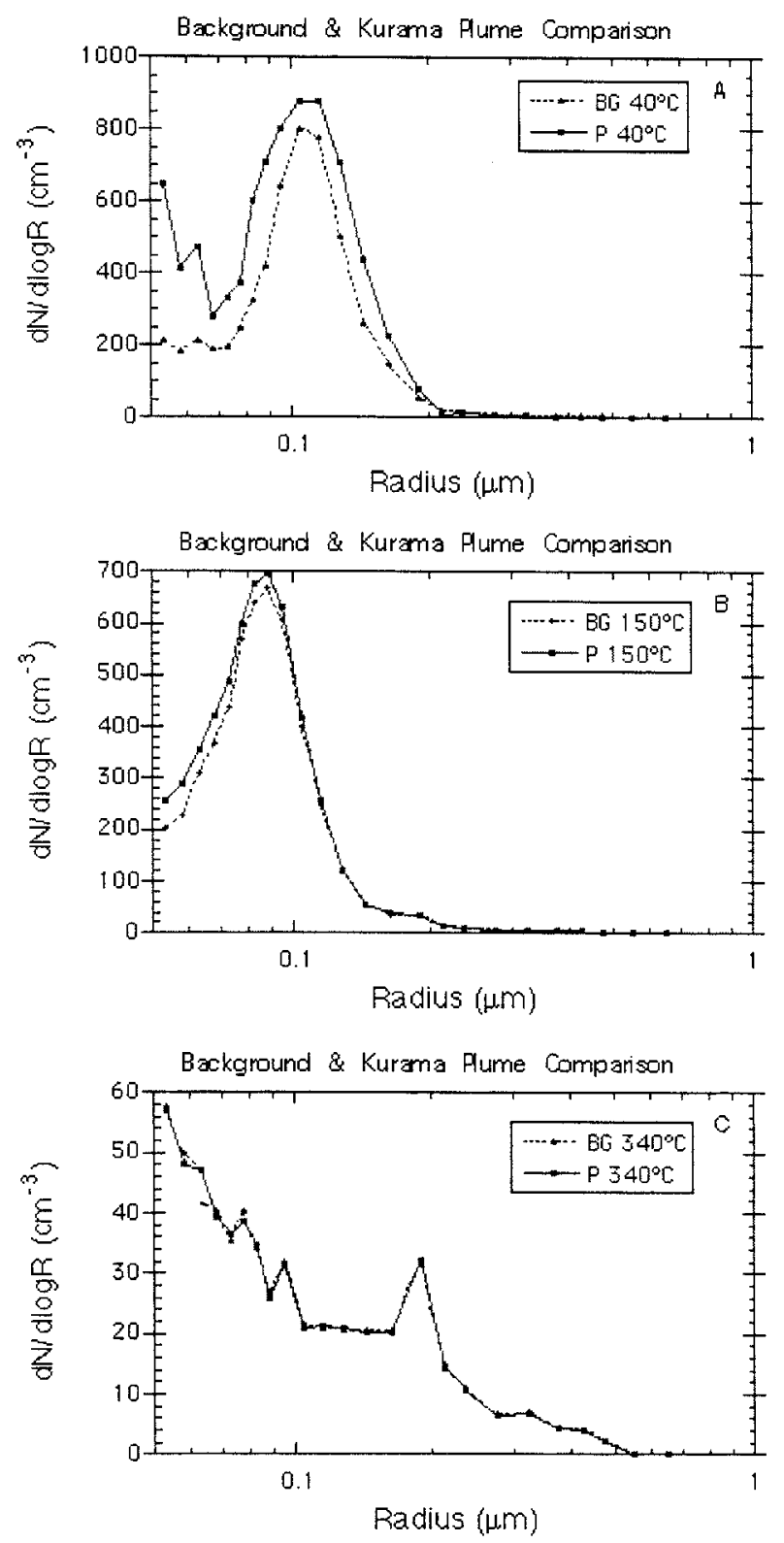

FIG. 8. Volatility of the plume (P) and background (BG) from C-130 measurements of the plume from the Kurama.

and many whitecaps were visible. There is no doubt that bubble breaking that occurs in the ship's water wake and at the hull produce some sea-salt aerosol. However, to be important this source must be comparable to the integrated source of sea salt along the upwind fetch.

Finally, single-particle analysis of cloud droplet residual aerosol from the CVI primarily in several young ship tracks showed no enhancement of sea salt compared with the surrounding clouds (Noone et al. 2000a,b). Taken together, these various types of measurements lead us to conclude that sea-salt particles from ships' wakes are not produced in sufficient numbers, or they are not lofted to cloud level quickly enough, to have a mea- 
surable influence on ship track formation. Therefore, we conclude that MAST hypothesis 1ii is not supported by evidence from the MAST experiment.

\section{Conclusions}

A broad array of observations and numerical model simulations have provided evidence that particles from the power stacks of ships are primarily responsible for modifications of cloud droplet numbers and sizes in marine boundary layer clouds and are therefore responsible for ship tracks. This analysis shows that the connecting relationships that are necessary for hypothesis $1 \mathrm{i}$ to be confirmed-from ship-induced $\mathrm{CCN}$ increases to satellite-observed cloud reflectance increases-are quantitatively verified in ship track observations. Measurements in ship plumes show that sufficient numbers of total particles, as well as those particles capable of acting as $\mathrm{CCN}$, are emitted from those ships that produce ship tracks, and these are generally diesel-powered ships. Ships that are less efficient producers of aerosols and CCN (steam and gas turbines) produce fewer and weaker ship tracks.

Ship tracks are observed to be more prolific and to exhibit stronger albedo enhancements when pollution is low in the ambient air (Platnick et al. 2000). Coakley et al. (2000) show that greater boundary layer depth is correlated with lack of ship track production. Also, Durkee et al. (2000a) show that boundary layer depth below about $800 \mathrm{~m}$ is a significant factor in determining the susceptibility of the marine boundary layer to ship track formation. These observations also support hypotheses $1 \mathrm{i}$ and 1ii since clean and shallow boundary layers will be more readily perturbed by the addition of ship particle effluents.

Observations from MAST provided no support for the hypothesis that sea-salt particles from ships' wakes produce ship track formation. Aerosol size distributions in ship plumes and ambient conditions indicate that far too few particles of the size expected from ship wakes $(>0.2-\mu \mathrm{m}$ radius) are observed. No ships, large or small, produced a recognizable signature of water-wake particles either in size distributions or chemical analysis.

Acknowledgments. The MAST project and this paper specifically were supported by numerous grants to the various coauthors under the Office of Naval Research Accelerated Research Initiative entitled Surface Ship Cloud Effects.

\section{REFERENCES}

Albrecht, B. A., 1989: Aerosols, cloud microphysics, and fractional cloudiness. Science, 245, 1227-1230.

Andreae, M. O., 1995: Climatic Effects of Changing Atmospheric Aerosol Levels. World Survey of Climatology, Vol. 16, Elsevier, $634 \mathrm{pp}$.

Blanchard, D. E., and A. D. Woodcock, 1980: The production, con- centration and vertical distribution of sea-salt aerosol. Ann. New York Acad. Sci., 338, 330-341.

Coakley, J. A., Jr., R. L. Bernstein, and P. A. Durkee, 1987: Effect of ship-stack effluents on cloud reflectivity. Science, 237, 10201022.

—, and Coauthors, 2000: The appearance and disappearance of ship tracks on large spatial scales. J. Atmos. Sci., 57, 2765-2778.

Conover, J. H., 1966: Anomalous cloud lines. J. Atmos. Sci., 23, 778785.

Durkee, P. A., and Coauthors, 2000a: Composite ship track characteristics. J. Atmos. Sci., 57, 2542-2553.

— K. K. J. Noone, and R. T. Bluth, 2000b: The Monterey Area Ship Track experiment. J. Atmos. Sci., 57, 2523-2541.

Ferek, R. J., D. A. Hegg, P. V. Hobbs, P. A. Durkee, and K. E. Nielsen, 1998: Measurements of ship-induced cloud tracks off the Washington coast. J. Geophys. Res., 103, 23 199-23 206.

- , and Coauthors, 2000: Drizzle suppression in ship tracks. $J$. Atmos. Sci., 57, 2707-2728.

Frick, G. M., and W. A. Hoppel, 2000: Airship measurements of ship's exhaust plumes and their effect on marine boundary layer clouds. J. Atmos. Sci., 57, 2625-2648.

Hindman, E. E., W. M. Porch, J. G. Hudson, and P. A. Durkee, 1994: Ship-produced cloud lines of 13 July 1991. Atmos. Environ., 28, 3393-3403.

Hobbs, P. V., L. F. Radke, J. H. Lyons, R. J. Ferek, D. J. Coffman, and T. J. Casadevall, 1991: Airborne measurements of particle and gas emissions from the 1990 volcanic eruptions of Mount Redoubt. J. Geophys. Res., 96, 18 735-18 752.

— their effects on clouds. J. Atmos. Sci., 57, 2570-2590.

Hoppel, W. A., and G. M. Frick, 1990: Submicron aerosol size distributions measured over the tropical and South Pacific. Atmos. Environ., 25A, 645-659.

Hudson, J. G., 1991: Observations of anthropogenic cloud condensation nuclei. Atmos. Environ., 25A, 2449-2455.

— T. J. Garrett, P. V. Hobbs, S. R. Strader, Y. Xie, and S. S. Yum, 2000: Cloud condensation nuclei and ship tracks. J. Atmos. Sci., 57, 2696-2706.

IPCC, 1995: Climate Change 1995: The Science of Climate Change. Cambridge University Press, $584 \mathrm{pp}$.

Mineart, G. M., 1988: Multispectral satellite analysis of marine stratocumulus cloud microphysics. M.S. thesis, Department of Meteorology, Naval Postgraduate School, 149 pp. [Available from Naval Postgraduate School, 589 Dyer Road, Monterey, CA 93943.]

Noone, K. J., J. A. Ogren, J. Heintzenberg, R. J. Charlson, and D. S. Covert, 1988: Design and calibration of a counterflow virtual impactor for sampling of atmospheric fog and cloud droplets. Aerosol Sci. Technol., 8, 235-244.

_ - and Coauthors, 2000a: A case study of ship track formation in a polluted marine boundary layer. J. Atmos. Sci., 57, 2748-2764.

- , and Coauthors, 2000b: A case study of ships forming and not forming tracks in moderately polluted clouds. J. Atmos. Sci., 57, 2729-2747.

O'Dowd, C., and M. H. Smith, 1993: Physicochemical properties of aerosols over the northeast Atlantic: Evidence for wind speedrelated submicron sea-salt aerosol production. J. Geophys. Res., 98, 1137-1149.

Platnick, S., and Coauthors, 2000: The role of background cloud microphysics in the radiative formation of ship tracks. J. Atmos. Sci., 57, 2607-2624.

Porch, W. M., C. J. Kao, and R. G. Kelley Jr., 1990: Ship trails and ship induced cloud dynamics. Atmos. Environ., 24A, 1051-1059.

Radke, L. F., and P. V. Hobbs, 1969: Measurement of cloud condensation nuclei, light scattering coefficient, sodium-containing particles, and Aitken nuclei in the Olympic Mountains of Washington. J. Atmos. Sci., 26, 281-288.

, J. A. Coakley Jr., and M. D. King, 1989: Direct and remote sensing observations of the effects of ships on clouds. Science, 246, 1146-1149. 
Russell, L. M., R. C. Flagan, and J. H. Seinfeld, 1995: Asymmetric inversion effects resulting from flow non-idealities in accelerated differential mobility measurements. Aerosol Sci. Technol., 23, 491-509.

— , S.-H. Zhang, R. C. Flagan, and J. H. Seinfeld, 1996: Radially classified aerosol detector for aircraft-based submicron aerosol measurements. J. Atmos. Oceanic Technol., 13, 598-609.

- , K. J. Noone, R. J. Ferek, R. A. Pockalny, R. C. Flagan, and J. H. Seinfeld, 2000: Combustion organic aerosol as cloud condensation nuclei in ship tracks. J. Atmos. Sci., 57, 2591-2606.

Slingo, A., 1990: Sensitivity of the Earth's radiation budget to changes in low clouds. Science, 343, 49-51.
Taylor, J. P., M. P. Glew, J. A. Coakley Jr., W. R. Tahnk, S. Platnick, P. V. Hobbs, and R. J. Ferek, 2000: Effects of aerosols on the radiative properties of clouds. J. Atmos. Sci., 57, 2656-2670.

Twomey, S., 1974: Pollution and the planetary albedo. Atmos. Environ., 8, 1251-1256.

Xhoffer, C., L. Wouters, and R. Van Grieken, 1992: Characterization of individual particles in the North Sea surface microlayer and underlying seawater: Comparison with atmospheric particles. Environ. Sci. Technol., 26, 2151-2162.

Zhang, S. H., Y. Akutsu, L. M. Rusell, R. C. Flagan, and J. H. Seinfeld, 1995: Radial differential mobility analyzer. Aerosol Sci. Technol., 23, 357-372. 